\title{
Characterization and classification of soils on grazing lands in Kwallatawa village, Sokoto State, Nigeria
}

\author{
Hayatu, N.G. ${ }^{1}{ }^{*}$, S.S. Noma ${ }^{1}$, A. Nabayi ${ }^{2}$, M.M. Abdelsatter ${ }^{3}$, F.D. Haruna ${ }^{4}$, A. Amadou ${ }^{5}$, I. Sani ${ }^{6}$, \\ M.B. Sharu ${ }^{7}$ A.B. Anka ${ }^{8}$ and S.D. Abubakar ${ }^{9}$
}

${ }^{1}$ Department of Soil Science and Agricultural Engineering, Usmanu Danfodiyo University, Sokoto, Nigeria. ${ }^{2}$ Department of Soil Science, Federal University Dutse, Jigawa state. Nigeria. ${ }^{3}$ Department of Animal and Poultry Production, South Valley University, Qena, Egypt. ${ }^{4}$ Department of Soil Science, Federal University Dutsinma, Katsina State. ${ }^{5}$ Key Laboratory of Plant Nutrition and Fertilization, Institute of Agricultural Resources and Regional Planning, Chinese Academy of Agricultural Sciences, China. ${ }^{6}$ Department of Chemistry, Zamfara State College of Education, Maru. ${ }^{7}$ Department of Agricultural Science, Shehu Shagari College of Education, Sokoto. ${ }^{8}$ Federal Ministry of Agriculture and Rural Development, Zamfara State. ${ }^{9}$ Department of Geography, Usmanu Danfodiyo University, Sokoto, Nigeria

\begin{abstract}
Continuous extensive land use without proper land management has the potential to degrade the inherent soil fertility. Kwallatawa grazing lands are experiencing such exploitation which if not properly addressed, can dwindle their potentials. To address this, characterization and classification of the soils were carried out at reconnaissance level to assess the properties of the grazing soils. Two pedons were dug and described following FAO (2006) guidelines. The results show that pedons Gra P1 and P2 had shallow to slightly deep genetic horizons. They also show discernible colour pattern at both topsoil and subsoil layers. The pedons were sandy in texture with moderate bulk density $\left(1.4 \mathrm{~g} \mathrm{Bd} \mathrm{cm}^{-3}\right)$ and low $(<50 \%)$ to high $(>50 \%)$ porosity at surface and subsurface horizons respectively. Similarly, the soils were moderately acidic (5.81 mean), low in organic carbon (2.3 g C/kg mean), CEC (5.37 $\mathrm{cmol}_{+} \mathrm{CEC} / \mathrm{kg}$ mean) as well as high in total nitrogen $(1.14 \mathrm{~g}$ $\mathrm{N} \mathrm{kg}^{-1}$ mean), exchangeable sodium $\left(>0.5 \mathrm{cmol}_{+} \mathrm{Na} \mathrm{kg}^{-1}\right)$ and percent base saturation $(>80 \%)$. The Pedons Gra-P1 and P2 were respectively classified following USDA Soil Taxonomy as Typic Ustipsamments and Lithic Ustipsamments, and then subsequently correlated with WRB for Soils Classification as Eutric Arenosols (Arenic) and Plinthic Arenosols (Arenic). Our results revealed the soils to be acidic and fall within low to medium fertility class, as such liming and incorporation of organic residue were recommended to checkmate their deficiencies.
\end{abstract}

Keywords: Kwallatawa, Grazing lands, Pedons, Soil characterization, Classification

\section{Introduction}


Any direct anthropogenic activity that relates to land in terms of using its resources to derive goods and/or services or both, both within

*Corresponding author: madny2018@gmail.com Received: October 20, 2020;

Accepted: November 21, 2020;

Published: November 23, 2020.

short and/or long term is referred to as land use. However, continuous extensive land use without proper land management has the potential to degrade its inherent soil fertility. Soils have been perceived and defined differently by different category of disciplines, here we perceived it, as that twoor three-dimensional natural entity possessing genetic horizons (2-dimensional body) or layers (3-dimesnional body) emanating from minerals or organic materials or both, that are of different thickness, with distinct features from their precursors biologically, chemically, mineralogically, morphologically and physically (Birkeland, 1999). The divergent behaviours exhibited by different soil types could be specifically attributed to the variability in their biological, chemical, mineralogical, morphological and physical characteristics. Broadly, the differences could be attributed to the influence of the soil forming factors and soil forming processes acting upon the soils parent material (Soil Survey Staff, 1993). Hence, the characteristics of soils on our farms, gardens, airports, recreational sites, forests, orchards, schools, septic and sewage disposal system and those around our houses, roads, shopping canters differed and exert varying influence on our pursuits. Therefore, these soils have to be treated as special and separate entities (Broderson, 2000).

Nigeria has an estimated land area of 92, 377, 000 hectares (or 923, $770 \mathrm{~km}^{2}$ ) with an estimated population of around 206.14 million inhabitants (Statista, 2020). According to Asadu et al. (2004), land use differs from one locality to another owing to differences in norms and values of the localities. Majorly, these revolved around agricultural (such as irrigation, orchard, forests, aquaculture etc), industrial (such as oil mining, coal and gold mining etc) and infrastructural (such as roads, schools, hospitals etc) land uses. Asadu et al. (2004) reported that of the total land mass of Nigeria, $\sim 65 \%$ was devoted to food and forest sectors distributed into $42 \%$ (crop production), $21 \%$ (open grazing and livestock projects), <2\% (plantation) and $<1 \%$ (cultivation of denuded areas). However, FAOSTAT (2014) reported that Nigeria's total land mass (FAO, 2014) includes $33 \%$ (permanent meadows and pasture), 37\% (arable land), 7\% (permanent crops) and 7\% (forests). According to Asadu et al. (2004), available data between 19761995 revealed drastic shrinkage in land mass by $16,13,>400 \%$ and $>150 \%$ under crop, grazing and livestock, plantation and denuded areas respectively leading to increase by $>500 \%$ and $>1,000 \%$ areas under sand dunes, and under gullies and salty marsh respectively. That is why Olagunju (2015) opined that about 64 percent of Nigerian total land mass is prone to desertification, which could be ascribed to consequential effects of overgrazing (FAO, 2018).

The fringes of Kware town is blessed with vast potentially cultivable land under different land utilization types such as rainfed arable farming, irrigated arable cultivation, open grazing lands, orchard plantation among others. The soils being closer to the town are exposed to extensive use, which if not properly controlled, has a potential of degrading the fertility of the soils. Soil and land use and management studies will help in averting these situations. Evaluation of land performance for a given purpose such grazing is however, the answer. This is because evaluation provides information necessary for 
the understanding of soil properties and their response to a given use which is essential in addressing the issue relating to the transformation and sustainability of agroecosystem (Yao et al., 2010). Although, some studies relating to the soils of Sokoto state have been conducted (Noma and Gabasawa, 2005; Noma et al. 2005; Yakubu, 2006; Sharu et al. 2013; Lukman et al. 2014), none of such studies focused on the potential of grazing soils of Kware Local Government. Therefore, the objective of this study was to characterize, classify the soils of the area in addition to highlighting some of the effects of grazing on the soil characteristics.

\section{Materials and Methods}

\section{1- Study Site}

This study was carried out at Kwallatawa village, Kware Local Government area, Sokoto, Nigeria. Kware is located between latitude $13^{0} 0^{\circ} 0^{\prime \prime}$ to $13^{\circ} 20^{\circ} 0^{\prime \prime} \mathrm{N}$ and longitude $5^{0} 10^{\prime} 0^{\prime \prime}$ to $5^{0} 30^{\prime} 0^{\prime \prime} \mathrm{E}$ with an area of $554 \mathrm{~km}^{2}$ (Latitude, 2016). Kwallatawa is located between latitude $13^{0} 12^{\prime} 22.87^{\prime \prime}$ to $13^{0}$ $122^{`} 36.06^{\prime \prime} \mathrm{N}$ and longitude $5^{0} 12^{`} 49.49^{\prime \prime}$ to $5^{0} 12^{\prime} 0.00 "$ E (Figure 1). The area has tropical climate characterized by an average rainfall of $565 \mathrm{~mm} /$ year (NMA, 2011). The minimum temperature is $27{ }^{0} \mathrm{C}$ while the maximum temperature is $40{ }^{\circ} \mathrm{C}$ (NMA, 2011).
It has relative humidity of about $15-20 \%$ during dry season and reaches up to 70-75\% during the rainy season. Agriculture especially crop and livestock production are the dominant activities engaged by the people of Kwallatawa villages. Other land uses include residential, quarry, mining and roads construction etc. The dominant underlying geology of the study area is Cretaceous and Tertiary sediments (Sombroek and Zonneveld, 1971). The vegetation is typical of Sudan zone, characterized by savannah woodland and shrub savannah.

\section{2- Field Work}

Two (2) farmers plots located at Kwallatawa village were purposely selected for the study. The farms were reserved for over 20 years for grazing. The general site description such as climate, vegetation, land use, slope gradient, drainage type and condition, type and degree of erosion and depth to ground water table were recorded. Two profile pits $(2 \times 1.5 \times 2$ $\mathrm{m})$ were dug and described morphologically following FAO (2006) guidelines. For each profile, depth, colour, texture, structure, consistence, roots, pores, inclusions, as well as boundary characteristics were recorded. The coordinates of the study area pedons were recorded using global positioning system (GPS) device. 


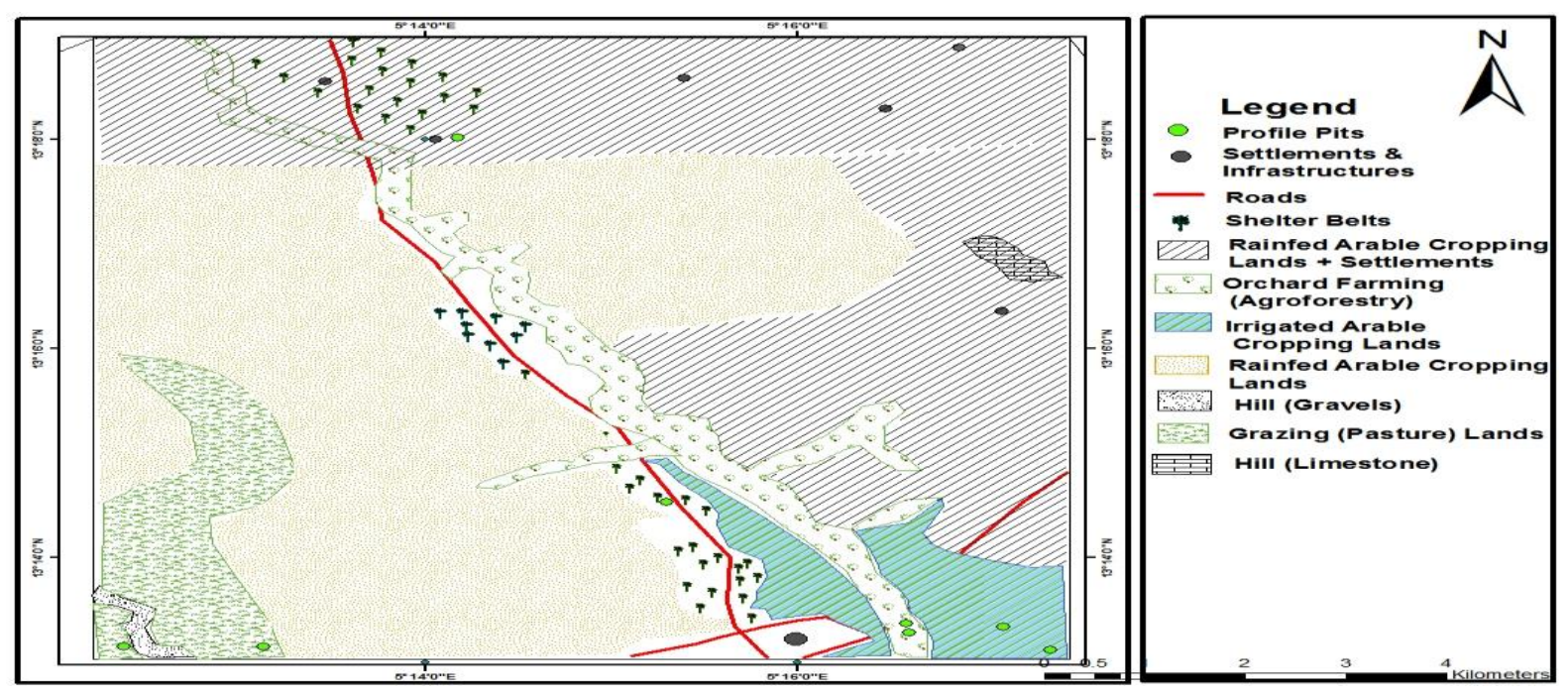

Figure 1: A map showing different land use types and location of grazing lands 


\section{3- Samples Collection and Preparation:}

Both disturbed and undisturbed soil samples were taken from each genetic horizon of the two pedons. Undisturbed soil samples for bulk density determination were taken with core samplers of known volume, whereas disturbed samples for physical and chemical parameters determination were taken in nylons, labelled accordingly and transported to the laboratory. The undisturbed soil samples were oven dried for 48 hours at 105 ${ }^{\circ} \mathrm{C}$. Disturbed soil samples on the other hand, were air-dried for 48 hours and ground to pass through $2 \mathrm{~mm}$ sieve.

\section{4- Laboratory Analyses}

The prepared soil samples were analyzed for particle size distribution following Bouyoucos Hydrometer (ISRIC/FAO, 2002) method. Bulk density was determined as described by Blake and Hartge (1986). Particle density was determined following Black (1965) Pycnometer bottle method. Total porosity was extrapolated using the particle and bulk density values as shown in the equation below:

$$
\mathrm{P}=1-\left[\frac{\mathrm{Bd}}{\mathrm{Pd}}\right] \times 100
$$

$\mathrm{Bd}=\frac{\text { Weight of ovendried soil sample at } 105^{\circ} \mathrm{C}}{\text { Total Volume of fresh soil sample }}$ (2)

where, $\mathrm{P}$ is porosity, $\mathrm{Bd}$ is bulk density ( $\mathrm{g}$ $\left.\mathrm{cm}^{-3}\right), \mathrm{Pd}$ is particle density (\%) of the soil

A glass electrode $\mathrm{pH}$ meter was used to determine soil $\mathrm{pH}$ both in water and $0.01 \mathrm{M}$ $\mathrm{CaCl}_{2}$ with 1:2.5 soil to liquid ratio (Thomas, 1996). Nelson and Sommers (1996) wet oxidation method was followed to determined organic carbon. Total nitrogen, available phosphorus and CEC were respectively determined using the Micro-Kjeldahl digestion and distillation method (Bremner, 1996), Bray No. 1 method and determined using molybdenum blue method (Kuo, 1996) and the neutral ammonium acetate saturation method buffered at pH 7 (ISRIC/FAO, 2002).
Neutral $1 \mathrm{~N} \mathrm{NH}_{4} \mathrm{OAC}$ saturation method was used to determine exchangeable bases (ISRIC/FAO, 2002). After the extraction, atomic absorption spectrophotometer (AAS) was used to read $\mathrm{Ca}$ and $\mathrm{Mg}$, and Flame Photometer was used to read $\mathrm{K}$ and $\mathrm{Na}$. Percentage base saturation of the soils was extrapolated using the following equation:

$$
\mathrm{PBS}=\frac{\sum(\mathrm{Ca}, \mathrm{Mg}, \mathrm{K}, \mathrm{Na})}{\mathrm{CEC}} \times 100
$$

where; PBS is percent base saturation (\%), CEC is cation exchange capacity $\left(\mathrm{cmol}_{+} \mathrm{kg}^{-1}\right)$

\section{5- Data Analysis}

The data obtained were subjected to descriptive statistics such as mean, range and percentage using Excel (2016).

\section{Results and Discussions}

\section{1- Morphological properties}

The morphological characteristics of Pedons Gra P1 and P2 under grazing lands are presented in Table 1. Both pedons of the grazing land had shallow to slightly deep (Gra-P2; $76 \mathrm{~cm}$ and Gra-P1; $120 \mathrm{~cm}$ ) profiles. Pedon Gra-P1 had four genetic soil horizons (A-BA-BC1-BC2), Pedon Gra-P2 consisted of two horizons (A-BC-2C). The surface layers were formed from deposition and accumulation of humified organic materials from grasses as observed by Dessalegn et al. (2014) and gravels from weathered rock residua, which contributed immensely to the surface roughness of the land (Plate 1). The study is not at far with Dessalegn et al. (2014) in that subsurface layers were formed due to wet-dry cycles that aggregated clay-textured soil particles into blocky peds, since it is crystal clear that there was no evidence of structural formation (Plate 1 and 2).

The pedons had shown discernible variations in the colour patterns at both surface and subsoil. The colours differed from strong brown (7.5YR4/6) to yellow red (5YR5/8) dry 
in Pedons Gra P1 and P2 surface layers respectively (Table 1) depicting the influence of topography, location, weathering and parent material. The colour of the subsurface horizons ranged from yellowish red (BA and $\mathrm{BC} 1)$ and pinkish white $(\mathrm{BC} 2)$ to red $(\mathrm{BC})$ in Pedon Gra P1 and P2 subsurface layers respectively. From this result, it can be deduced that the soils had low organic matter content contradicting Chimdi et al. (2012) findings that, grazing land were high organic matter content when compared with cultivated lands, which they attributed to lower surface area and presence of higher $\mathrm{Fe}$ and $\mathrm{Al}$ oxides contents due to highly weathered nature of cultivated soils.

The results (Table 1) revealed that both Pedons had similar horizon thickness, horizon boundary and soft soil structure ranging from weak medium crumb in the surface layers to structureless at the subsurface layers. The result also did not show great variability in relation to soil texture, indicating the similarity in parent material.

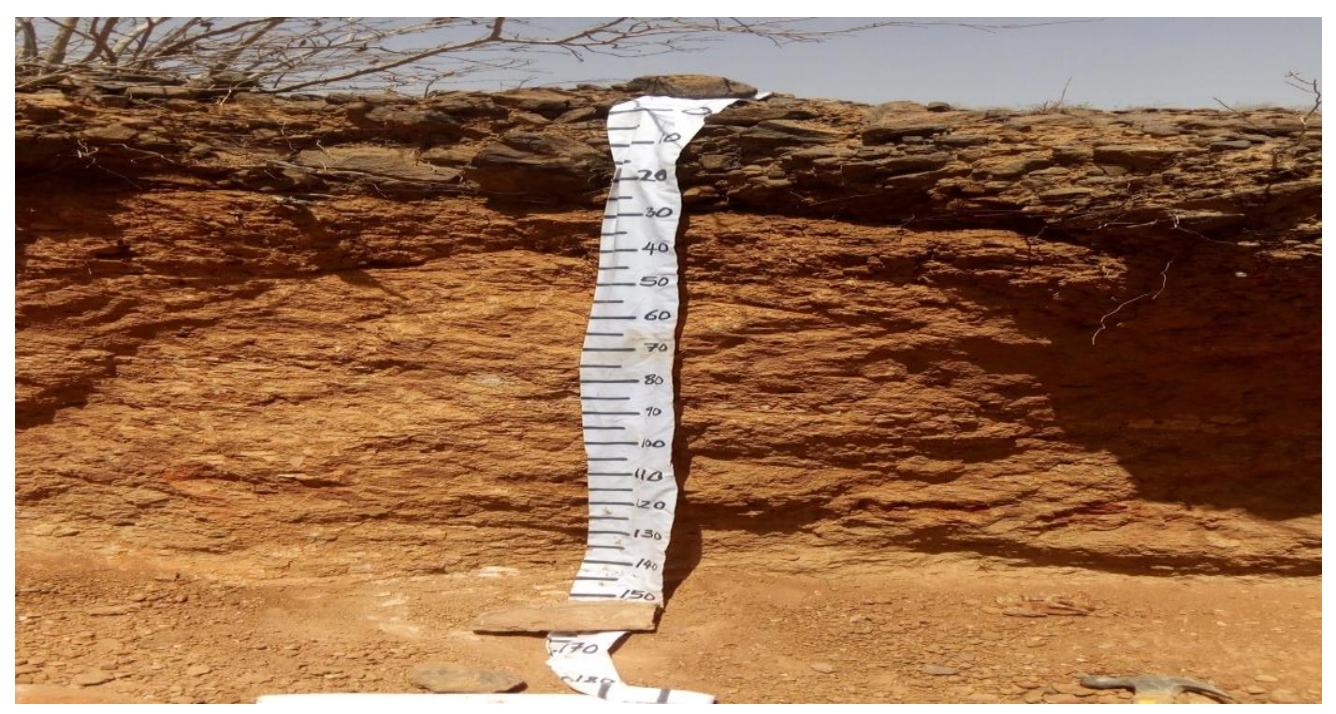

Plate 1: Pedon Gra-P1 showing horizons and gravelly surface horizon

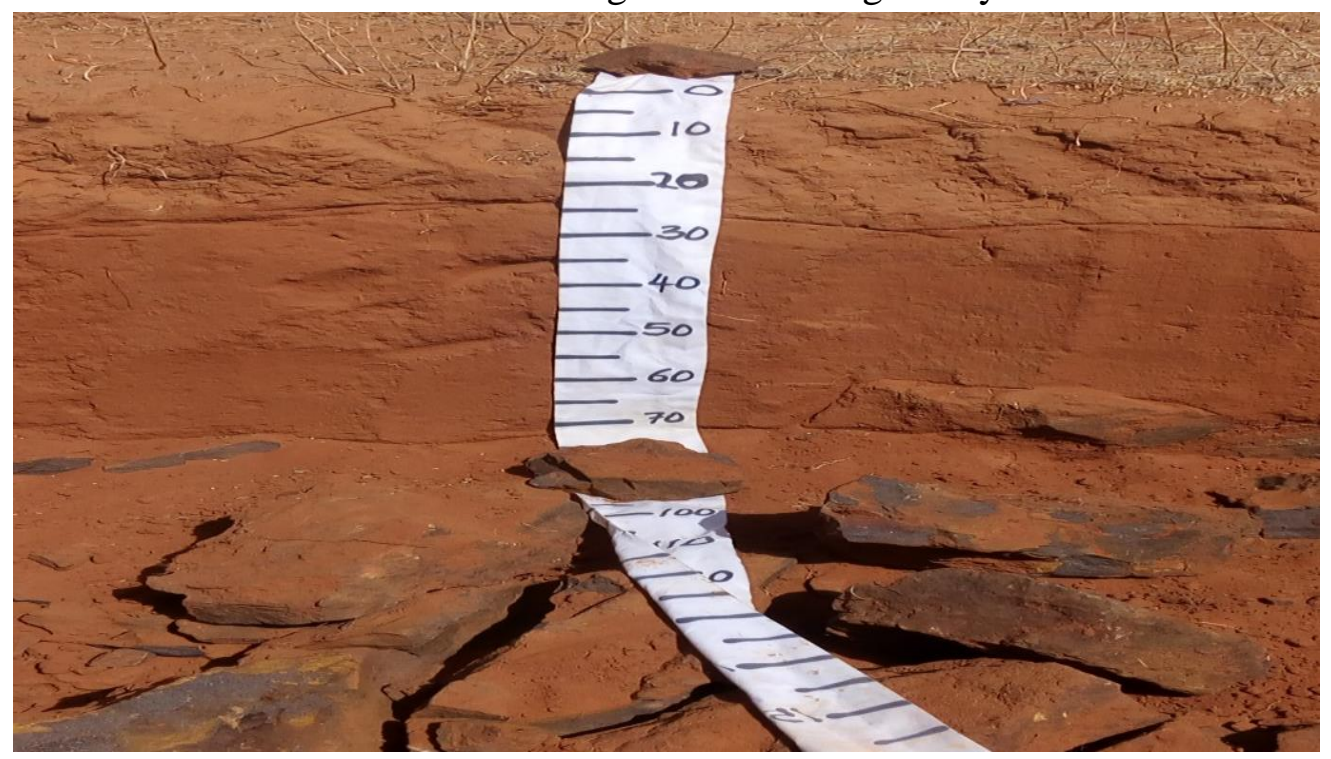

Plate 2: Pedon Gra-P2 showing impermeable layer with plinthic materials

Table 1: Morphological Properties of Pedons Gra P1 and P2 
Hayatu et al., SVU-International Journal of Agricultural Sciences, 2 (2): 326-338, 2020

\begin{tabular}{|c|c|c|c|c|c|c|c|}
\hline Horizon & $\begin{array}{c}\text { Depth } \\
(\mathrm{cm})\end{array}$ & Colour & Texture $^{1}$ & Structure $^{2}$ & Consistence $^{3}$ & Boundary ${ }^{4}$ & $\begin{array}{c}\text { Other } \\
\text { Features }\end{array}$ \\
\hline
\end{tabular}

Kwallatawa Series- Pedon Gra P1 (Typic Ustipsamments/Eutric Aresonols (Arenic)

$\begin{array}{cccccccc}\text { A } & 0-29 & 7.5 Y R 4 / 6 & \mathrm{~S} & \text { wmc } & \mathrm{s} & \mathrm{ds} & \begin{array}{c}\mathrm{mfmr}, \\ \mathrm{mfp},\end{array} \\ \mathrm{BA} & 29-54 & 5 \mathrm{YR} 5 / 6 & \mathrm{~S} & \text { wmc } & \mathrm{s} & \mathrm{ds} & \begin{array}{c}\mathrm{mfmr}, \\ \mathrm{mmp}, \mathrm{ffcf}\end{array} \\ \mathrm{BC} 1 & 54-83 & 5 \mathrm{YR} 4 / 6 & \mathrm{~S} & \text { Structureless } & \mathrm{s} & \mathrm{ds} & \mathrm{fmr}, \\ \mathrm{BC} 2 & 83- & 5 \mathrm{YR} 8 / 2 & \mathrm{~S} & \text { Structureless } & \mathrm{s} & \mathrm{ds} & \mathrm{fmr}, \mathrm{fff} \\ \mathrm{fmp}, \mathrm{ffcf}\end{array}$

Kwallatawa Series- Pedon Gra P2 (Lithic Ustipsamments/Plinthic Aresonols (Arenic)

$\begin{array}{cclccccc}\text { A } & 0-26 & 5 Y R 5 / 8 & \mathrm{~S} & \text { wmc } & \mathrm{s} & \text { ds } & \begin{array}{c}\mathrm{mmr}, \mathrm{ffp} \text {, } \\ \mathrm{mmcf}\end{array} \\ \text { BC } & 26-76 & 2.5 \mathrm{YR} 4 / 6 & \mathrm{~S} & \text { Structureless } & \mathrm{s} & \mathrm{dw} & \mathrm{fmr}, \mathrm{ffp} \\ \text { 2C } & >76 & \text { Plinthic layer, indurated } & & & \end{array}$

${ }^{1} \mathrm{~S}=\mathrm{sand},{ }^{2} \mathrm{wmc}=$ weak medium crumb, ${ }^{3} \mathrm{~s}=$ soft, ${ }^{4} \mathrm{ds}=$ diffuse soft, $\mathrm{dw}=$ diffuse wavy, ${ }^{5} \mathrm{mfmr}=$ many fine and medium roots, $\mathrm{fmr}=$ fine medium roots, $\mathrm{mmr}=$ many medium roots, $\mathrm{mfp}=$ medium fine pores, $\mathrm{mmp}=$ many medium pores, $\mathrm{ffp}=$ few fine pores, $\mathrm{mmcf}=$ many medium coarse fragments, $\mathrm{ffcf}=\mathrm{few}$ fine coarse fragments

\section{2- Physical properties}

The soil texture was generally sandy (Table 2) both at the topsoil and subsoil layers of both pedons. The topsoil layers of Pedons Gra P1 and $\mathrm{P} 2$ has sand contents that ranged between 89.6 to $91.6 \%$ (90.6\% mean) and was rated high. The silt and clay values of the soils ranged from 1.4 to $5.9 \%(3.7 \%)$ and 2.5 to $9.0 \%(5.8 \%)$ respectively and were rated very low. For the underlying horizons, the sand, silt and clay contents varied from 89.6 to $91.6 \%$ (90.6\%), 1.4 to $5.9 \%$ (3.7\%) and 2.5 to $9.0 \%$ $(5.8 \%)$ respectively. The results have agreed with the findings by DAFF (2013) and Rueda et al. (2020) who observed that the most suitable soils for pasture and grazing are sandy soils, loamy soils or clay soils. However, the sandy nature of the soils could be ascribed to the nature of the parent materials.

The $\mathrm{Bd}$ values of the surface horizons of Pedons Gra P1 and P2 ranged from 1.3 to 1.4 $\mathrm{gcm}^{-3}$ (1.4 $\mathrm{g} \mathrm{cm}^{-3}$ mean) and was rated moderate. In the subsurface horizons, bulk density values varied from 1.3 to $1.5 \mathrm{gcm}^{-3}$ $\left(1.4 \mathrm{~g} \mathrm{~cm}^{-3}\right.$ mean) and was also rated moderate (Table 2). The moderate bulk density values could be ascribed to the sandy nature of the soils and paedogenic processes taking place therein. Our results were in line with that of Sonneveld (2005), who observed that, bulk density of the soils of the Northern region of Nigeria is about $1.4 \mathrm{gcm}^{-3}$. This result has further indicated low stocking rate or generally low grazing activities taken place on the soils, as their bulk densities are still below the critical value of $1.6 \mathrm{gcm}^{-3}$ that can hinder proper growth and development of grazing pasture.

Total porosity followed similar trend with bulk density (Table 2). In the surface horizons of Pedons Gra P1 and P2, the total porosity varied from 43 to $46 \%$ (45\%) and was rated low. For subsurface horizons, total porosity ranged from 51 to $60 \%$ (56\%) and was rated high. The eroded soil particles that filled the pore spaces could have led to the moderate bulk densities $\left(1.4 \mathrm{gcm}^{-3}\right)$ and lower total 
porosity (43 and 46\%) observed in the horizons of both pedons.

Table 2: Physical Properties of Pedons Gra P1 and P2

\begin{tabular}{|c|c|c|c|c|c|c|c|c|}
\hline \multirow[t]{2}{*}{ Horizon } & \multirow{2}{*}{$\begin{array}{c}\text { Depth } \\
\text { (cm) }\end{array}$} & \multicolumn{3}{|c|}{$\begin{array}{l}\text { Particle Size Distribution } \\
(\%)\end{array}$} & \multirow{2}{*}{$\begin{array}{c}\text { Textural } \\
\text { Class }\end{array}$} & $\mathrm{Bd}$ & $\mathrm{Pd}$ & \multirow{2}{*}{$\begin{array}{l}\text { Porosity } \\
(\%)\end{array}$} \\
\hline & & Sand & Silt & Clay & & \multicolumn{2}{|c|}{$\mathrm{gcm}^{-3}$} & \\
\hline \multicolumn{9}{|c|}{ Kwallatawa Series- Pedon Gra P1 (Typic Ustipsamments/Eutric Aresonols (Arenic) } \\
\hline A & $0-29$ & 89.6 & 1.4 & 9.0 & S & 1.3 & 2.6 & 46 \\
\hline BA & $29-54$ & 89.6 & 1.4 & 9.0 & $S$ & 1.3 & 2.5 & 56 \\
\hline $\mathrm{BC} 1$ & $54-83$ & 91.6 & 5.9 & 2.5 & S & 1.4 & 2.4 & 58 \\
\hline $\mathrm{BC} 2$ & $83-120^{+}$ & 91.6 & 5.9 & 2.5 & S & 1.5 & 2.5 & 60 \\
\hline \multicolumn{9}{|c|}{ Kwallatawa Series- Pedon Gra P2 (Lithic Ustipsamments/Plinthic Aresonols (Arenic) } \\
\hline A & $0-26$ & 91.6 & 5.9 & 2.5 & $S$ & 1.4 & 2.5 & 43 \\
\hline $\mathrm{BC}$ & $26-76$ & 91.6 & 5.9 & 2.5 & S & 1.5 & 2.6 & 51 \\
\hline $2 \mathrm{C}$ & $>76$ & \multicolumn{7}{|c|}{ Plinthic layer, indurated } \\
\hline $\mathrm{Mc}$ & & 90.9 & 4.4 & 4.7 & $S$ & 1.4 & 2.5 & 52 \\
\hline S & & 2.71 & 1.39 & 2.21 & - & 0.08 & 0.04 & 3.12 \\
\hline
\end{tabular}

$\mathrm{SE}=$ standard error, $\mathrm{S}=$ sand, $\mathrm{Bd}=$ bulk density, $\mathrm{Pd}=$ particle density

\section{3- Chemical properties}

$\mathrm{pH}$ values of the surface horizons of Pedons Gra P1 and P2 ranged from 5.76 to 5.85 (5.81 mean) and was rated moderately acidic. For underlying horizons, $\mathrm{pH}$ values varied from 5.48 to 5.75 (5.62 mean) and was also rated moderately acidic (Table 3). Similar $\mathrm{pH}$ values were previously reported from cattle grazing system (Rueda et al. 2020). The $\mathrm{pH}$ values appeared similar among the Pedons Gra P1 and P2 and did not vary much with depth. The EC values in the surface horizons of Pedons Gra P1 and P2 varied between 0.01 to 0.05 ( $0.02 \mathrm{dS} \mathrm{m}^{-1}$ mean) and was rated low. According to Horneck et al. (2008), $\mathrm{pH}$ values between 6-7 were the ideal $\mathrm{pH}$ range for pasture, though pasture plants can withstand a wide range of soil $\mathrm{pH}$. However, grass yields are usually reduced when soil $\mathrm{pH}$ drops below 5.1. This shows that the $\mathrm{pH}$ (water) of these soils (Table 3) are good for pasture grass as it does not fall below the critical value of 5.1 and did not exceeds 7.0.

The OC content of the topsoil soils ranged from 0.60 to $3.99 \mathrm{~g} \mathrm{C} \mathrm{kg}^{-1}$ ( $2.30 \mathrm{~g} \mathrm{C} \mathrm{kg}^{-1}$ mean), which is generally low. For the underlying soils, OC content varied from 0.98 to $4.40 \mathrm{~g} \mathrm{C} \mathrm{kg}^{-1}$ (2.69 $\mathrm{g} \mathrm{C} \mathrm{kg}^{-1}$ ) and was also rated low (Table 3). The low OC could be attributed to the low organic matter and texture of the soils. Correlation analysis showed insignificant negative relationship between sand and silt contents with OC $(\mathrm{r}=$ $0.805, \mathrm{P}>0.05$ ) contents, and also between OC and soil $\mathrm{pH}(\mathrm{r}=-0.299, \mathrm{P}>0.05)$ (Table 4). The low OC values were not similar with that obtained by Chimdi et al. (2012) and Dessalegn et al. (2014) who observed significantly higher OC values in grazing land as compared to other land use types.

Total nitrogen content in the surface horizons of Pedons Gra P1 and P2 ranged from 0.88 to $1.39 \mathrm{~g} \mathrm{~N} \mathrm{~kg}^{-1}$ (1.14 $\mathrm{g} \mathrm{N} \mathrm{kg}^{-1}$ mean) which was rated high. For the subsurface horizons, TN values varied between 0.97 to $3.16 \mathrm{~g} \mathrm{~N} \mathrm{~kg}^{-1}$ (2.07 $\mathrm{g} \mathrm{N} \mathrm{kg}^{-1}$ mean) and were also rated high (Table 3). The total nitrogen content of the soils varied irregularly with depth. Chimdi et al. (2012) observed similar values under grazing land, contrary to Horneck et al. (2008) 
who opined that, nitrogen is the most deficient nutrients in many grass pasture soils, since the grasses used it the most as compared to other nutrients.

The available phosphorus content in the surface horizons of Pedons Gra P1 and P2 ranged from 11.69 to $20.36 \mathrm{mg} \mathrm{P} \mathrm{kg}^{-1}$ (16.03 $\mathrm{P} \mathrm{mg} \mathrm{kg}{ }^{-1}$ mean) and was rated medium. For the subsurface horizons, available phosphorus content varied from 7.54 to $28.28 \mathrm{mg} \mathrm{P} \mathrm{kg}^{-1}$ (17.91 $\mathrm{mg} \mathrm{P} \mathrm{kg}^{-1}$ mean) and was also rated medium (Table 3). The low available phosphorus values (7.54 $\mathrm{mg} \mathrm{P} \mathrm{kg}^{-1}$ ) observed in Pedon Gra-P1 could be attributed to Pfixation. According to Mishra et al. (2004), lower available $\mathrm{P}$ values in grazing land may be due to lower soil organic matter status. Correlation analysis indicated negative but insignificant relationship between available phosphorus $(\mathrm{r}=-0.546, \mathrm{P}>0.05)$ and organic carbon (Table 4).

The exchangeable bases contents in the topsoil horizons of Pedons Gra P1 and P2 ranged from 2.00 to $4.81 \mathrm{cmol}_{+} \mathrm{Ca} \mathrm{kg}^{-1}$ (3.41 $\mathrm{cmol}_{+} \mathrm{Ca} \mathrm{kg}^{-1}$ mean), 0.68 to $0.70 \mathrm{cmol}_{+} \mathrm{Mg}$ $\mathrm{kg}^{-1}$ (0.69 $\mathrm{cmol}_{+} \mathrm{Mg} \mathrm{kg}^{-1}$ mean), 0.03 to 0.08 $\mathrm{cmol}_{+} \mathrm{K} \mathrm{kg}^{-1}$ (0.06 $\mathrm{cmol}_{+} \mathrm{K} \mathrm{kg}^{-1}$ mean) and 0.55 to $0.99 \mathrm{cmol}_{+} \mathrm{Na} \mathrm{kg}^{-1}\left(0.77 \mathrm{cmol}_{+} \mathrm{Na} \mathrm{kg}^{-}\right.$ 1 mean) respectively. For the underlying horizons, $\mathrm{Ca}, \mathrm{Mg}, \mathrm{K}$ and $\mathrm{Na}$ content varied from 2.95 to $4.59 \mathrm{cmol}_{+} \mathrm{Ca} \mathrm{kg}^{-1}\left(3.77 \mathrm{cmol}_{+}\right.$ $\mathrm{Ca} \mathrm{kg}{ }^{-1}$ mean), 0.38 to $0.65 \mathrm{cmol}_{+} \mathrm{Mg} \mathrm{kg}^{-1}$ (0.51 $\mathrm{cmol}_{+} \mathrm{Mg} \mathrm{kg}^{-1}$ mean), 0.03 to 0.05 $\mathrm{cmol}_{+} \mathrm{K} \mathrm{kg}^{-1}\left(0.04 \mathrm{cmol}_{+} \mathrm{K} \mathrm{kg}^{-1}\right.$ mean $)$ and 0.57 to $0.94 \mathrm{cmol}_{+} \mathrm{Na} \mathrm{kg}^{-1}\left(0.76 \mathrm{cmol}_{+} \mathrm{Na} \mathrm{kg}^{-}\right.$ ${ }^{1}$ mean) respectively. The exchangeable bases complex of the soils (Table 3 ) is dominated by $\mathrm{Na}$ in the following sequence $\mathrm{Na}>\mathrm{Ca}>\mathrm{Mg}>\mathrm{K}$ i.e. the least in abundance is potassium. The low $\mathrm{K}$ could be attributed to imbalance between nutrient loss via crop removal and those applied via fertilizers.

The cation exchange capacity in the surface horizons of Pedons Gra P1 and P2 varied from
3.70 to $6.80 \mathrm{cmol}_{+} \mathrm{CEC} \mathrm{kg}^{-1}\left(5.25 \mathrm{cmol}_{+} \mathrm{CEC}\right.$ $\mathrm{kg}^{-1}$ mean) and was rated low. For the underlying horizons, CEC values ranged 4.80 to $6.20 \mathrm{cmol}_{+} \mathrm{CEC} \mathrm{kg}^{-1}\left(5.50 \mathrm{cmol}_{+} \mathrm{CEC} \mathrm{kg}^{-1}\right.$ mean) and was also rated low (Table 3). The low CEC values could be due to texture and low OC content (Tables 2 and 3 ) of the soils. The result contradicts that of Mganga et al. (2011) who recorded high CEC values (up to $19.59 \mathrm{cmol}_{+} \mathrm{CEC} \mathrm{kg}^{-1}$ ) in an open grazing land. Soils with cation exchange capacity of $<16 \mathrm{cmol}_{+} \mathrm{kg}^{-1}$ are considered not to be fertile and such soils are highly weathered while fertile soils have a cation exchange capacity of $>24 \mathrm{cmol}_{+} \mathrm{kg}^{-1}$. The result shows that these soils are not fertile judging by their CEC values.

The base saturation of the soils was generally high (Table 3), ranging from 88.65 to $96.47 \%$ ( $92.56 \%$ mean) in the surface horizons of Pedons Gra P1 and P2. For the subsurface horizons, percent base saturation varied from 92.22 to $96.67 \%$ (94.45\% mean). The percent base saturation was similar for both Pedons Gra P1 and P2. The high base saturation observed could be ascribed to the inherent characteristics of the parent materials. In this result, insignificant negative relationship between base saturation and soil $\mathrm{pH}(\mathrm{r}=$ $0.521, \mathrm{P}>0.05$ ) was observed (Table 4).

\section{4- Soil Classification}

The soils were classified following the United State Department of Agriculture (USDA) Soil Taxonomy System guidelines (USDA-NRCS, 2010) which was later Correlated with World Reference Base 
Table 3: Chemical Properties of Pedons Gra P1 and P2

\begin{tabular}{|c|c|c|c|c|c|c|c|c|c|c|c|c|}
\hline \multirow[t]{2}{*}{ Horizon } & \multirow[t]{2}{*}{ Depth $(\mathrm{cm})$} & $\mathrm{pH}(1: 2.5)$ & \multirow[t]{2}{*}{$\mathrm{EC} \mathrm{dSm}{ }^{-1}$} & OC & $\mathrm{TN}$ & \multirow{2}{*}{$\begin{array}{c}\mathrm{AP} \\
\mathrm{mgkg}^{-1}\end{array}$} & $\mathrm{Ca}$ & $\mathrm{Mg}$ & $\mathrm{K}$ & $\mathrm{Na}$ & CEC & \multirow{2}{*}{$\begin{array}{l}\mathrm{BS} \\
(\%)\end{array}$} \\
\hline & & Water & & \multicolumn{2}{|c|}{$\mathrm{gkg}^{-1}$} & & \multicolumn{5}{|c|}{ cmol+ kg-1 } & \\
\hline \multicolumn{13}{|c|}{ Kwallatawa Series- Pedon Gra P1 (Typic Ustipsamments/Eutric Aresonols (Arenic) } \\
\hline A & $0-29$ & 5.76 & 0.01 & 3.99 & 1.39 & 11.69 & 4.81 & 0.68 & 0.08 & 0.99 & 6.80 & 96.47 \\
\hline BA & $29-54$ & 5.69 & 0.01 & 4.40 & 3.16 & 13.20 & 4.59 & 0.45 & 0.05 & 0.83 & 6.20 & 95.48 \\
\hline $\mathrm{BC} 1$ & $54-83$ & 5.48 & 0.05 & 3.40 & 1.08 & 13.95 & 4.15 & 0.38 & 0.04 & 0.94 & 5.70 & 96.67 \\
\hline $\mathrm{BC} 2$ & $83-120^{+}$ & 5.54 & 0.01 & 1.60 & 0.97 & 7.54 & 2.95 & 0.62 & 0.05 & 0.82 & 4.80 & 92.50 \\
\hline \multicolumn{13}{|c|}{ Kwallatawa Series- Pedon Gra P2 (Lithic Ustipsamments/Plinthic Aresonols (Arenic) } \\
\hline A & $0-26$ & 5.85 & 0.01 & 0.60 & 0.88 & 20.36 & 2.00 & 0.70 & 0.03 & 0.55 & 3.70 & 88.65 \\
\hline $\mathrm{BC}$ & $26-76$ & 5.75 & 0.01 & 0.98 & 2.35 & 28.28 & 3.73 & 0.65 & 0.03 & 0.57 & 5.40 & 92.22 \\
\hline $2 \mathrm{C}$ & $>76$ & \multicolumn{11}{|c|}{ Plinthic layer, indurated } \\
\hline & ean & 5.68 & 0.03 & 2.50 & 1.64 & 15.84 & 3.71 & 0.58 & 0.48 & 0.78 & 5.43 & 93.67 \\
\hline & $\mathrm{E}$ & 0.19 & 0.02 & 0.95 & 0.32 & 3.17 & 2.08 & 0.13 & 0.03 & 0.15 & 2.16 & 0.94 \\
\hline
\end{tabular}

$\mathrm{SE}=$ standard error, $\mathrm{pH}=$ soil reaction, $\mathrm{EC}=$ electrical conductivity, $\mathrm{OC}=$ organic carbon, $\mathrm{TN}=$ total nitrogen, $\mathrm{AP}=$ available phosphorus, $\mathrm{CaCl}=\mathrm{calcium}$ chloride,

$\mathrm{Ca}=$ calcium, $\mathrm{Mg}=$ magnesium, $\mathrm{K}=$ potassium, $\mathrm{Na}=$ sodium, $\mathrm{CEC}=$ cation exchange capacity, $\mathrm{Mg}=$ magnesium, $\mathrm{BS}=$ base saturation 
Table 4: Correlation (r) Analysis of the Soils of Kwallatawa Series Pedons Gra P1 and P2

\begin{tabular}{|c|c|c|c|c|c|c|c|c|c|c|c|c|c|c|c|}
\hline & Sand & Silt & Clay & $\mathrm{Bd}$ & Por & $\mathrm{pH}$ & $\mathrm{OC}$ & TN & $\mathrm{AP}$ & $\mathrm{Ca}$ & $\mathrm{Mg}$ & $\mathrm{K}$ & $\mathrm{Na}$ & CEC & BS \\
\hline Silt & $1.000 * *$ & & & & & & & & & & & & & & \\
\hline Clay & $-1.000 * *$ & $-1.000 * *$ & & & & & & & & & & & & & \\
\hline $\mathrm{Bd}$ & -0.204 & -0.204 & 0.204 & & & & & & & & & & & & \\
\hline Por & 0.151 & 0.151 & -0.151 & $-0.972 * *$ & & & & & & & & & & & \\
\hline $\mathrm{pH}$ & -0.256 & -0.256 & 0.256 & $0.925 * *$ & $-0.902 *$ & & & & & & & & & & \\
\hline $\mathrm{OC}$ & -0.805 & -0.805 & 0.805 & -0.273 & 0.277 & -0.299 & & & & & & & & & \\
\hline $\mathrm{TN}$ & -0.537 & -0.537 & 0.537 & -0.042 & 0.159 & 0.187 & 0.397 & & & & & & & & \\
\hline $\mathrm{AP}$ & 0.356 & 0.356 & -0.356 & 0.518 & -0.463 & 0.541 & -0.546 & 0.267 & & & & & & & \\
\hline $\mathrm{Ca}$ & -0.723 & -0.723 & 0.723 & -0.142 & 0.243 & -0.231 & 0.873 & 0.539 & -0.226 & & & & & & \\
\hline $\mathrm{Mg}$ & 0.088 & 0.088 & -0.088 & $0.764 * *$ & -0.696 & $0.709 *$ & -0.598 & -0.294 & 0.284 & -0.462 & & & & & \\
\hline K & -0.763 & $-0.763 * *$ & $0.763 * *$ & 0.113 & -0.052 & -0.033 & 0.683 & -0.011 & -0.648 & 0.628 & 0.097 & & & & \\
\hline $\mathrm{Na}$ & $-0.531 * *$ & -0.531 & $0.531 * *$ & -0.399 & 0.395 & -0.567 & 0.842 & -0.079 & -0.776 & 0.715 & $-0.475^{* *}$ & 0.789 & & & \\
\hline CEC & -0.758 & -0.758 & 0.758 & -0.077 & $0.189 * *$ & -0.188 & 0.859 & 0.478 & -0.279 & 0.989 & $-0.349 * *$ & 0.726 & 0.744 & & \\
\hline BS & -0.573 & -0.573 & 0.573 & -0.383 & 0.429 & -0.521 & 0.905 & 0.275 & -0.461 & 0.927 & -0.631 & 0.630 & 0.891 & 0.911 & \\
\hline $\mathrm{EC}$ & -0.632 & -0.632 & 0.632 & $-0.258 * *$ & 0.263 & 0.040 & 0.571 & 0.812 & -0.175 & 0.407 & -0.481 & 0.088 & 0.124 & 0.345 & $0.285^{* *}$ \\
\hline
\end{tabular}

$\mathrm{Bd}=$ bulk density, $\mathrm{Por}=$ porosity, $\mathrm{OC}=$ organic carbon, $\mathrm{TN}=$ total nitrogen, $\mathrm{AP}=$ available phosphorus, $\mathrm{Ca}=$ calcium, $\mathrm{Mg}=$ magnesium, $\mathrm{K}=$ potassium, $\mathrm{Na}=$ sodium, $\mathrm{CEC}=$ cation exchange capacity, $\mathrm{BS}=$ base saturation, $\mathrm{EC}=$ electrical conductivity 
(WRB) for Soil Resources (WRB-IUSS, 2014).

\subsection{Classification following USDA Soil Taxonomy:}

Kwallatawa Series: These soil units were classified at order level as Entisol, because they did not fit into other soil orders of USDA system. At suborder level soils of Kwallatawa series were classified as Psamments, because of their sandy nature. They were further classified as Ustipsamments at great-group level due to Ustic moisture regime. However, at subgroup level:

- Kwallatawa Series (Gra-P1): it was categorized as Typic Ustipsamments, for not fitting into other subgroups of the order Entisols.

- Kwallatawa Series (Gra-P2): was classified as Lithic Ustipsamments due to lithic contact it posses within the $50 \mathrm{~cm}$.

\subsection{Correlation with WRB for Soil Classification:}

- Kwallatawa Series (Gra-P1): Having a soil texture class of loamy sand, this soil unit was at RSG of WRB system classified as Arenosols. Having a base saturation $\left(\mathrm{NH}_{4} \mathrm{OAC}\right.$ buffered at $\mathrm{pH}$ 7) above 50 percent, it was ascribed to Eutric Arenosols. It was further classified as Eutric Arenosols (Arenic) at supplementary qualifier level, since it shows a texture class of sand in a layer $>30 \mathrm{~cm}$ thick but within $<100 \mathrm{~cm}$.

- Kwallatawa Series (Gra-P2): Being predominantly sandy in nature, this soil unit was classified as Arenosols at RSG level of WRB system. Also, having a plinthic layer that started $<100 \mathrm{~cm}$ from the topsoil, it was ascribed to Plinthic principal qualifier. Furthermore, the soils shows a textural class of sand within $<100 \mathrm{~cm}$ of the mineral soil surface, it was further categorized as Plinthic Arenosols (Arenic) at supplementary qualifier level.

\section{Conclusion}

The result showed that the grazing lands had soils from weathered rock residua and aeolian sand and were also well-drained. The pedons of the grazing lands had shallow to slightly deep layers with different genetic horizons designations and discernible colour pattern but similar soil structure, depicting the influence of topography, location, weathering and parent material. Soils of grazing lands were sand in texture. Bulk density values of the grazing lands were below the critical value (1.6 $\mathrm{g} \mathrm{Bd} \mathrm{cm-3).} \mathrm{The} \mathrm{soil} \mathrm{units} \mathrm{studied} \mathrm{were}$ low in organic carbon content and were moderately acidic. The available $\mathrm{P}$ values of the soils was rated medium across the soil profile. The soils were generally of low fertility class, except for exchangeable sodium and percent base saturation, which were observed to be high. The electrical conductivity of the soils across the grazing land were generally low. The soil was also found to be high in total $\mathrm{N}$.

\section{References}

Asadu, C.L.A., Ezeaku, P.I. and Nnagi, G.U. (2004) 'Land use and soil management situation in Nigeria: An analytical review of changes', Outlook on Agriculture. SAGE Publications. ISSN: 0030-7270. Online ISSN: 2043-6866.

Birkeland, P. (1999) 'Soils and Geomorphology', USA: Oxford University Press. ISBN: 0195078861. URL: http://researchbooks.org/0195078861. Accessed 15/10/2014.

Black, C.A. (1965) 'Methods of Soil and Plant Analyses', Agron. No.9, Part 2 Amer. Soc. Madison.

Blake, G.R. and Hartge, K.H. (1986) 'Bulk density', In A. Klute (Ed.), Methods of soil analysis. Part 1. Physical and mineralogical methods ( $2^{\text {nd }}$ edn.) Wisconsin: ASA-SSSA, pp. 363-375. 
Bremner, J.M. (1996) 'Nitrogen - Total', In:

D. L. Sparks (ed.), Methods of Soil Analysis Part 3 - Chemical Methods, SSSA Book Series 5, Madison, Wisconsin, USA, pp. $1085-1122$.

Broderson, W.D. (2000) 'From the surface down: An introduction to soil surveys for agronomic use', USDA. Natural Resources Conservation Services. Nation Employee Development Service. Washington, D.C., pp. 1-29.

Chimdi, A., Gebrekidan, H., Kibret, K. and Tadesse, A. (2012) 'Status of selected physicochemical properties of soils under different land use systems of Western Oromia, Ethiopia', Journal of Biodiversity and Environmental Sciences (JBES) 2(3), pp. 57-71.

DAFF (2013) 'Grazing BMP self-assessment: grazing land management', Northern Australian Module. The State of Queensland, Department of Agriculture, Fisheries and Forestry.

Dessalegn, D., Beyene, S., Ram, N., Walley, F. and Gala, T.S. (2014) 'Effects of topography and land use on soil characteristics along the toposequence of Ele-watershed in southern Ethiopia', Catena 115, pp. 47-54.

Excel (2016) 'Microsoft office excel spreadsheet', Version 2016.

FAO (2006) 'Guidelines for Soil Description', Fourth Edition. Food and Agriculture Organization of the United Nations Rome, Italy, pp. 109.

FAO (2018) 'Africa Sustainable Livestock 2050 (ASL 2050)', Livestock and environment spotlight. Nigeria cattle and poultry sectors. CA2150EN/1/10.18. Available at CC-BY-NC-SA-3.0. IGO licence. Accessed August $10^{\text {th }} 2020$.

FAO (2014) 'Country profile

- Nigeria', Available and accessed online on $15^{\text {th }} \quad$ July, 2020 at http://www.fao.org/countryprofiles/inde x/en/?iso3=NGA.

FAOSTAT (2017) 'Land use', Available online at: http://www.fao.org/faostat/en/\#data/RL. Accessed August $10^{\text {th }} 2020$.
Horneck, D.A., Sulliran, D.M., Owen, J.S. and Hart, J.M. (2011) 'Soil test interpretation guide', EC 1478. http://catalog.extension.oregonstate.edu/ ec1478 Oregon State University Extension Service.

IPCC (2019) 'Climate Change and Land. An IPCC Special Report on climate change, desertification, land degradation, sustainable land management, food security, and greenhouse gas fluxes in terrestrial ecosystems. Geneva', Intergovernmental Panel on Climate Change.

ISRIC/FAO (2002) 'Procedures for soil analysis', Sixth edition. In: L.P. Van Reeuwijik (ed.), International Soil Reference and Information Center/FAO, pp. 119.

Kuo, S. (1996) 'Phosphorus', In: D. L. Sparks (ed.), Methods of Soil Analysis, Part 3 Chemical Methods. SSSA Book Series 5, Madison, pp. 869 - 920.

Lukman, S.A., Noma, S.S., Yakubu, M., Audu, M., Abubakar, G.A. and Sauwa, M.M. (2014). 'Characterization and classification of soils of Adarawa village, Tangaza Local Government, Sokoto State', In: S.O. Ojeniyi, J.C. Obi, T.O. Ibia, P.I. Ogban and A.A. Onwukwe (eds). Proceedings of the $38^{\text {th }}$ Annual Conference of the Soil Science Society of Nigeria (SSSN) held at Department of Soil Science and Land Resources Management, University of Uyo, Uyo, Nigeria, pp. 10-14.

Mganga, K.Z., Musimba, N.K.R., Nyariki, D.M., Nyangito, M.M., Ekaya, W.N., Muiru, W.M. and Mwang'ombe, A.W. (2011) 'Different land use types in the semi-arid rangelands of Kenya influence soil properties', Journal of Soil Science and Environmental Management 2(11), pp. 370-374.

Mishra, B.B., Heluf, G. and Kibebew, K. (2004) 'Soils of Ethiopia: Perception Appraisal and Constraints in Relation to Food Security', Journal of Food, Agriculture and Environment 2(3\&4), pp. 269-279. 
Nelson, D.W. and Sommers, L.E. (1996)

'Total carbon, organic carbon and organic matter', In: D.L. Sparks (ed.), Methods of Soil Analysis Part 3 - Chemical Methods. SSSA Book Series 5, Madison, Wisconsin, USA, pp. $961-1010$.

NMA (2011) 'Nigerian Meteorological Agency', Sultan Abubakar International Airport Sokoto, Nigeria.

Noma, S.S. and Gabasawa, A.I. (2005). 'Assessment of the quality of water and irrigated soils of Sokoto-Rima Floodplains', Bulletin of SAN 26, pp. 6369.

Noma, S.S., Ojanuga, A.G., Ibrahim, S.A. and Iliya, M.A. (2005) 'Detailed soil survey of Sokoto- Rima Floodplain at Sokoto', In: F.K. Salako, M.T. Adetunji, A.G. Ojanuga, T.A. Arowolo and S.O. Ojeniyi (eds). Managing Soil Resources for Food Security and Sustainable Environment. Proceedings of the $29^{\text {th }}$ Annual Conf. of SSSN held at University of Agriculture, Abeokuta, Nigeria, Dec., pp. 6-10.

Rueda, B.L. McRoberts, K.C., Blake, R.W., Nicholson, C.F., Valentim, J.F. and Fernandes, E.C.M. (2020) 'Nutrient status of cattle grazing systems in the western Brazilian amazon', Cogent Food \& Agriculture 6, pp. 1-19. https://doi.org/10.1080/23311932.2020.1 722350

Sharu, M.B., Yakubu, M., Noma, S.S. and Tsafe, A.I. (2013) 'Characterization and classification of soils on an agricultural landscape in Dingyadi district, Sokoto State, Nigeria', Nigerian Journal of Basic and Applied Science (NJBAS) 21(2), pp.137-147.

Soil Survey Staff (1993) 'Soil Survey Manual', USA: Washington, United State Department of Agriculture Handbook No. 18. U.S. Govt. Printing Office, pp. 410.

Sombroek, W.G. and Zonneveld, I.S. (1971) 'Ancient Dune Fields and Fluviatile Deposits in the Rima-Sokoto River Basin (NW Nigeria) ', Netherlands: Wageningen, Soil Survey Papers, No.5 Netherlands Soil Survey Institute, pp. 1107.
Sonneveld, B.G. (2005) 'Dominant soils of Nigeria', ISRIC World Soil Information Database. Amsterdam. Retrieved $03^{\text {rd }}$ February, 2010.

Statista

https://www.statista.com/statistics/38226 4/total-population-of-nigeria/ , accessed on Saturday 2020-10-17.

Thomas, G.W. (1996) 'Soil pH and Soil Acidity', In: D. L. Sparks (ed.) Methods of Soil Analysis Part 3-Chemical Methods. SSSA Book Series 5, Madison, Wisconsin, USA, pp. $475-490$.

USDA-NRCS (2010) 'Keys to Soil Taxonomy', Eleventh Edition. United States Department of Agriculture/Natural Resources Conservation Service.

WRB-IUSS Working Group (2014) 'International Soil Classification System for Naming Soil and Creating Legends for Soil Maps'. http://www.fao.org

Yakubu, M. (2006) 'Genesis and classification of soils over different geological formations and surfaces in the Sokoto plains Nigeria', An Unpublished $\mathrm{PhD}$ Thesis submitted to the Department of Soil Science and Agricultural Engineering, Usmanu Danfodiyo University Sokoto.

Yao, M.K., Angui, P.K.T., Konate, S., Tondoh, J.E., Tano, Y., Abbadie, L. and Benest, D. (2010) 'Effects of land use types on soil organic carbon and nitrogen dynamics in Mid-West Cote d'Ivoire', European Journal of Scientific Research 40(2), pp. 211-222. 